Wojciech Tomasz MODZELEWSKI

Uniwersytet Warmińsko-Mazurski w Olsztynie

\title{
Dwie dekady stosunków Polski z Litwą - wymiar polityczny
}

\section{Przywrócenie stosunków dyplomatycznych}

\begin{abstract}
d momentu uchwalenia przez Radę Najwyższą LSRR „Aktu przywrócenia niepodległości Państwa Litewskiego" w marcu 1990 r., zaistniały warunki do wznowienia stosunków międzypaństwowych z Polska. Rząd RP wydał oświadczenie w sprawie deklaracji o przywróceniu państwa litewskiego, nawiązano kontakty międzyparlamentarne, a Sejm RP podjął stosowną uchwałę ${ }^{1}$. Mimo tego przez ponad rok Polska formalnie nie uznawała samodzielności Litwy, co wynikało z ówczesnych uwarunkowań międzynarodowych i polskiej polityki dwutorowości. Nadal istniał ZSRR, który takie uznanie mógłby potraktować jako ingerencje w sprawy wewnętrzne. Ponadto trwały negocjacje na temat wyprowadzenia z Polski wojsk radzieckich, a granicy polsko-litewskiej wciąż pilnowały radzieckie wojska pograniczne. Sytuacja uległa zasadniczej zmianie po klęsce moskiewskiego puczu w sierpniu 1991 r. Jako pierwsza stosunki dyplomatyczne z Litwą nawiązała Islandia, następnie Dania, Norwegia i Szwecja - ta jako pierwsza otworzyła 29 sierpnia 1991 r. ambasadę w Wilnie ${ }^{2}$. W dniu 26 sierpnia 1991 r. premier Jan Krzysztof Bielecki listownie poinformował premiera Litwy Gediminasa Vagnoriusa o gotowości nawiązania stosunków międzypaństwowych z Republiką Litewską, co de facto oznaczało uznanie jej suwerenności. Wymiana listów w tej sprawie nastąpiła 2 września, a 5 września 1991 r. oficjalnie przywrócono stosunki dyplomatyczne między obu krajami. W październiku otwarto ambasadę litewską w Warszawie, a w listopadzie polską w Wilnie ${ }^{3}$.
\end{abstract}

1 Uchwała Sejmu Rzeczypospolitej Polskiej z dnia 22 marca 1990 r. w sprawie Litwy, http://isap.sejm.gov.pl.

2 J. Widacki, Stosunki z Litwa, ,Rocznik Polskiej Polityki Zagranicznej 1997”, http://www.sprawymiedzynarodowe.pl/rocznik/1997/1997.html.

3 Obecnie Polska, obok ambasady i jej wydziału konsularnego, ma także Instytut Polski w Wilnie, punkt konsularny w Kownie oraz konsulat honorowy w Kłajpedzie. 
Do czasu wynegocjowania i podpisania międzypaństwowego traktatu, głównym dokumentem regulującym wzajemne stosunki była $D e$ klaracja o przyjaznych stosunkach i dobrosqsiedzkiej wspótpracy między Rzeczapospolita Polska a Republika Litewska podpisana w Wilnie 13 stycznia 1992 r. przez ministrów spraw zagranicznych Krzysztofa Skubiszewskiego i Algirdasa Saudargasa. Podnosiła m.in. kwestie wzajemnego poszanowania suwerenności państwowej oraz integralności terytorialnej, traktowania mniejszości narodowych zgodnie z międzynarodowymi standardami, ochrony zabytków historii i kultury, wspólnego dążenia do umownego uregulowania współpracy gospodarczej i ekologicznej ${ }^{4}$.

Wraz z deklaracją zawarto także konwencję konsularną, a później szereg innych umów, m.in. ds. handlu i współpracy gospodarczej, ochrony środowiska czy wspólnej granicy państwowej ${ }^{6}$. Warto w tym miejscu podkreślić, iż na początku lat 90 . XX wieku na ponad $100 \mathrm{~km}$ polsko-litewskiej granicy nie było żadnego przejścia granicznego o charakterze międzynarodowym. Do takich potrzeb najpierw prowizorycznie zaadaptowano lokalne przejście w Ogrodnikach-Lazdijai, jednak jego mała przepustowość powodowała konieczność kilkudniowego oczekiwania na odprawę. Jesienią 1992 r. uruchomiono kolejowe przejście graniczne w Trakiszkach-Mockawa oraz przystąpiono do budowy nowoczesnego, dużego przejścia drogowego w Budzisku-Kalwarija. Równocześnie modernizowano i powiększano przejście w Ogrodnikach, a w 2006 r. uruchomiono przejście sezonowe Berżniki-Kapciamiestis. W latach 90. zawarto umowy dwustronne o ruchu bezwizowym oraz o współpracy i wzajemnej pomocy w sprawach celnych ${ }^{7}$. W związku z przystąpieniem

${ }^{4}$ W związku z 20 rocznicą podpisania deklaracji, w styczniu 2012 r. polskie MSZ wydało stosowne oświadczenie. Zob. Oświadczenie Ministerstwa Spraw Zagranicznych z okazji 20. rocznicy podpisania Deklaracji o przyjaznych stosunkach i dobrosqsiedzkiej wspótpracy między Rzeczapospolita Polskq a Republikq Litewska, http://www.msz.gov.pl.

${ }_{5}$ Konwencja konsularna między Rzeczapospolita Polskq a Republikq Litewska, sporzqdzona w Wilnie dnia 13 stycznia 1992 r. (Dz. U 1994, Nr 30, poz. 108), http://isap.sejm.gov.pl.

${ }^{6}$ Umowa między Rzeczapospolita Polskq a Republikq Litewskq o wspólnej granicy państwowej, stosunkach prawnych na niej obowiqzujacych oraz o wspótpracy $i$ wzajemnej pomocy $w$ sprawach granicznych, sporzqdzona $w$ Wilnie dnia 5 marca 1996 r., http://isap.sejm.gov.pl.

7 M. Błaszczuk, Wspótpraca transgraniczna i międzyregionalna $w$ stosunkach Polski z Republikami Battyckimi, w: Wspótpraca transgraniczna Polski z krajami 
obu krajów do Strefy Schengen w grudniu 2007 r. zniesiono kontrolę na wspólnej granicy.

W procesie odbudowy wzajemnych relacji nie brakowało kwestii problemowych. Trudności sprawiała m.in. sprawa statusu mniejszości polskiej na Litwie $^{8}$ oraz interpretacja niektórych wydarzeń ze złożonej historii obu narodów, głównie z okresu międzywojennego i II wojny światowej ${ }^{9}$. Poglądy głoszone przez niektóre nacjonalistyczne ugrupowania litewskie oraz polityka ówczesnych władz litewskich godząca w mniejszość polską ${ }^{10}$, rodziły niepokój nie tylko wśród Polaków na Litwie, ale także w Polsce. Wydarzenia te stały się poważnym hamulcem w rozwoju wzajemnych stosunków i spowodowały odsunięcie w czasie momentu podpisania traktatu polsko-litewskiego.

Sytuacja uległa poprawie po zmianie rządu litewskiego w połowie 1992 r. $^{11}$ oraz wyborach prezydenckich na Litwie i parlamentarnych w Polsce w 1993 r. Nowy układ polityczny przełamał impas we wzajemnych relacjach. Obie strony powoli przezwyciężały zaszłości historyczne, koncentrując się głównie na przyszłości. Ułatwiała to zbieżność celów polityk zagranicznych obu państw, wynikająca z dążenia do integracji z zachodnimi strukturami współpracy oraz podobnego postrzegania ich roli w kształtowaniu nowego ładu europejskiego. W 1992 r.

battyckimi, Białorusiq i Rosja-Obwód Kaliningradzki. Uwarunkowania i perspektywy rozwoju. Materiaty konferencyjne, Białystok 2002, s. 534-536.

8 Część litewskich Polaków dążyła do uzyskania autonomii politycznej w postaci Polskiego Kraju Narodowościowo-Terytorialnego z własną flagą godłem i hymnem. Władze litewskie ostro zwalczały ten postulat, nie popierały go także władze polskie.

${ }^{9}$ Dotyczyło to m.in. akcji militarnej gen. Lucjana Żeligowskiego w 1920 r. oraz działalności partyzanckiej Armii Krajowej na Wileńszczyźnie podczas II wojny światowej.

${ }_{10}$ Na przykład, w odpowiedzi na działania polskich autonomistów, we wrześniu 1991 r. rozwiązano rady samorządowe w rejonach solecznickim i wileńskim zamieszkałych głównie przez Polaków oraz wprowadzono tam komisaryczny zarząd, pozbawiając tym samym społeczność polską reprezentacji na szczeblu samorządowym. $\mathrm{Na}$ to posunięcie zareagowały władze polskie. Nastąiła wymiana listów między prezydentem Lechem Wałęsą a przewodniczącym parlamentu Vytautasem Landsbergisem, komisje spraw zagranicznych Sejmu i Senatu RP wydały oświadczenie $\mathrm{z}$ żądaniem zawieszenia tej decyzji, a polski MSZ złożył w tej sprawie notę protestacyjną.

${ }_{11}$ Po odwołaniu centroprawicowego rządu G. Vagnoriusa, powołano centrowy rząd A. Abisala. W dniu 28 września 1992 r. miała miejsce pierwsza w historii oficjalna wizyta w Polsce premiera Republiki Litewskiej. 
udało się uzyskać zgodę władz litewskich na uporządkowanie części wojskowej cmentarza na Rossie. Problemem trudnym do rozwiązania była nadal kwestia oceny działalności Armii Krajowej na Wileńszczyźnie. Chodziło nie tylko o sprawy natury prestiżowej, ale o konsekwencje praktyczne, takie jak możliwość legalnego zorganizowania się środowiska weteranów AK na Litwie oraz upamiętniania ich miejsc walk i pochówków. Ostatecznie zarejestrowano na Litwie Stowarzyszenie Weteranów Armii Krajowej oraz dwa inne polskie stowarzyszenia kombatanckie ${ }^{12}$.

W dniu 26 kwietnia 1994 r. prezydenci obu krajów Lech Wałęsa i Algirdas Brazauskas podpisali w Wilnie Traktat między Rzeczapospolita Polska a Republika Litewska o przyjaznych stosunkach $i$ dobrosqsiedzkiej wspótpracy. W jego preambule strony „pomne złożoności historii naszych narodów oraz wielowiekowej bliskości Polaków i Litwinów, biorąc pod uwagę możliwości odmiennego rozumienia wspólnej historii przez oba narody”, wyrażają ,żal z powodu konfliktów między obydwoma państwami po zakończeniu I wojny światowej, kiedy po długotrwałej niewoli Polacy i Litwini przystępowali do budowy nowego, niepodległego życia oraz potępiając używanie przemocy, które się zdarzało w stosunkach wzajemnych obu narodów"13. Traktat zawarto na 15 lat z klauzulą automatycznej prolongaty na okresy 5-letnie, jeśli żadna ze stron nie wypowie go na rok przed upływem danego okresu.

Określił on zasady współpracy w wielu dziedzinach wzajemnych stosunków, potwierdzono w nim także zapisy deklaracji ze stycznia 1992 r. Strony zobowiązały się do ułatwiania i popierania wzajemnej współpracy na płaszczyźnie dwustronnej oraz w ramach instytucji międzynarodowych. Po ratyfikowaniu przez parlamenty obu państw, wszedł on $\mathrm{w}$ życie $\mathrm{z}$ chwilą wymiany dokumentów ratyfikacyjnych w listopadzie 1994 r. Jego podpisanie wieńczyło proces ustanawiania przyjaznych stosunków i dobrosąsiedzkiej współpracy między Polską a krajami sąsiedzkimi, a Litwa była ostatnim sąsiadem, z którym zawarto taki układ. Dla Litwy natomiast był to pierwszy traktat z jednym z czterech sąsiadów $^{14}$.

12 J. Widacki, Stosunki z Litwq..., op. cit.

13 Zob. Traktat między Rzeczapospolita Polska a Republikq Litewska o przyjaznych stosunkach i dobrosqsiedzkiej wspótpracy, sporzadzony w Wilnie dnia 26 kwietnia 1994 r. (Dz. U. 1995, Nr 15, poz. 71), http://isap.sejm.gov.pl.

14 Szerzej o kulisach jego podpisania zob. A. Firewicz, Litwa po raz drugi, Toruń 2001, s. 225-235. 
Jak ocenia były polski ambasador w Wilnie Jan Widacki: „Traktat miał ogromne znaczenie nie tylko polityczne, ale w przypadku Litwy także moralne i psychologiczne. Odprężenie po jego podpisaniu dało się odczuć nie tylko w sferze polityki, ale w tonie publicystyki, reakcjach wielu środowisk, zwłaszcza intelektualnych i inteligenckich. Nastapiło szerokie otwarcie na kontakty z Polską, ustąpiła też, tak odczuwalna wcześniej, nieufność i lęk przed Polską [...]. Po podpisaniu i ratyfikowaniu Traktatu stosunki polsko-litewskie weszły w zdecydowanie nową fazę - stały się przyjazne" ${ }^{\text {"15 }}$.

\section{Budowa strategicznego partnerstwa}

Priorytetem polityki zagranicznej Litwy w sferze bezpieczeństwa było przystapienie do euroatlantyckich struktur integracyjnych. Stało się to oficjalnie litewską racją stanu po wycofaniu wojsk radzieckich z terytorium Litwy z końcem sierpnia 1993 r. ${ }^{16}$ Litwa dostrzegła sens w strategicznym partnerstwie z Polską jako państwem, które chce i może udzielić jej wsparcia w tych staraniach. W deklaracji programowej rządu Gediminasa Vagnoriusa utworzonego po wyborach parlamentarnych w grudniu 1996 r. współpraca z Polska, jedynym państwem wymienionym indywidualnie, została określona jako priorytet polityki zagranicznej Litwy ${ }^{17}$. Zintensyfikowano kontakty polityczne, czego wyrazem była pierwsza zagraniczna wizyta nowo wybranego prezydenta Aleksandra Kwaśniewskiego właśnie na Litwie w marcu 1996 r. Prezydent wygłosił wówczas przemówienie, którego hasłem przewodnim było zdanie: „nie ma bezpiecznej Polski bez bezpiecznej Litwy" "18. Oficjalną wizytę w Polsce

15 J. Widacki, Stosunki z Litwa..., op. cit.

16 Warto podkreślić, iż było to pierwsze państwo, z którego wycofano wojsko byłego ZSRR. Szukając rozwiązań kwestii własnego bezpieczeństwa, Litwa skłaniała się pierwotnie ku ściślejszej współpracy z państwami skandynawskimi, poprzez stworzenie systemu bezpieczeństwa Bałto-Skandynawii. Szerzej: S. Przybyła, Podejście Litwy do bezpieczeństwa w regionie, Warszawa 1997; J. Kozakiewicz, Polityka bezpieczeństwa państw baltyckich, Kraków 2003.

17 B. Wizimirska, Stosunki z Litwa, „Rocznik Polskiej Polityki Zagranicznej 1998", http://www.sprawymiedzynarodowe.pl/rocznik/1998/1998.html.

18 Prezydent A. Kwaśniewski wielokrotnie podkreślał, iż strategiczne partnerstwo obu krajów było dla niego jednym z najważniejszych zadań w polityce zagranicznej podczas pierwszej kadencji. Niewątpliwie miało to wpływ na fakt przyznania mu 
prezydent Litwy Algirdas Brazaukas złożył natomiast w czerwcu 1997 r., a jednym z jej efektów było podpisanie wspólnej deklaracji o pogłębieniu stosunków i współpracy na rzecz uczestnictwa w NATO i UE oraz porozumienia o utworzeniu Komitetu Konsultacyjnego przy Prezydentach Polski i Litwy. Premierzy obu państw Włodzimierz Cimoszewicz i Gediminas Vagnorius podpisali w 1996 r. m.in. porozumienie o powołaniu wspólnej komisji do walki z przestępczością zorganizowaną. We wrześniu 1997 r. podczas oficjalnej wizyty W. Cimoszewicza na Litwie odbyło się inauguracyjne posiedzenie Rady ds. Współpracy między Rządami Rzeczypospolitej Polskiej i Republiki Litewskiej. W ramach tego organu o charakterze konsultacyjno-doradczym powołano wspólne komisje do spraw polityki zagranicznej i polityki bezpieczeństwa, gospodarki, oświaty, kultury i nauki, dziedzictwa kulturowego oraz mniejszości narodowych ${ }^{19}$. Po wyborach prezydenckich na Litwie w 1998 r., w pierwszą zagraniczną podróż nowy prezydent Valdas Adamkus udał się również do Polski.

Zbliżenie polsko-litewskie znalazło swój szczególny wyraz na płaszczyźnie parlamentarnej. Powołano m.in. Polsko-Litewskie Zgromadzenie Poselskie ${ }^{20}$, składające się z 20 posłów z każdej strony, którego inauguracyjne posiedzenie odbyło się w lipcu 1997 r. w Wilnie, gdzie uchwalono jego statut. W przyjętej wtedy deklaracji postanowiono m.in., iż obie strony będą prowadzić intensywny dialog w kwestii integracji ze strukturami europejskimi i euroatlantyckimi oraz dbać o przestrzeganie praw mniejszości narodowych obu państw. Na jubileuszowej sesji Zgromadzenia w czerwcu 2007 r. w Warszawie, w dziesiątą rocznicę pierwszego posiedzenia, przyjęto Wspólnq deklarację, przestanie do Narodów Polski $i$ Litwy oraz oświadczenie skierowane do Parlamentu Europejskiego i Zgromadzenia Parlamentarnego NATO. W ostatnim z dokumentów zawarto stwierdzenie: „Zgromadzenie uznaje, że oba państwa w swej polityce wewnętrznej i zagranicznej opierają się na wspólnych zasadach i wartościach euroatlantyckich - demokracji, państwa prawa,

w 1999 r. najwyższego odznaczenia litewskiego - orderu Wielkiego Księcia Litwy Giedymina, a prezydent Litwy otrzymał Order Orła Białego. Zob. http://www.kwasniewskialeksander.pl.

19 B. Wizimirska, Stosunki z Litwa..., op. cit.

20 Inne nazwy tego organu występujące w literaturze przedmiotu to: Polsko-Litewska Grupa Międzyparlamentarna, Zgromadzenie Poselskie Sejmu Rzeczypospolitej Polskiej i Republiki Litewskiej. 
poszanowaniu praw człowieka w tym praw mniejszości narodowych. Zajmując należne im miejsce w zjednoczonej Europie oraz jednolitej euroatlantyckiej przestrzeni bezpieczeństwa, oba nasze państwa wykazały się zdecydowaniem i umiejętnością przezwyciężania wszelkich nieporozumień oraz stworzyły stabilne partnerstwo strategiczne"21.

Koniec lat 90. XX wieku był okresem wyjątkowo intensywnych kontaktów politycznych na najwyższych szczeblach, a oba kraje oficjalnie uznały się za partnerów strategicznych ${ }^{22}$. Regularne spotkania głów państw i szefów rządów z częstotliwością kilku rocznie stały się trwałym elementem wzajemnych relacji. Podczas piątej wizyty prezydenta Kwaśniewskiego na Litwie, ale pierwszej jako szefa państwa członkowskiego NATO w 1999 r., powiedział on: „Mamy poczucie wspólnoty doświadczeń, szczególnie w cieniu epoki jałtańskiej i w wyzwalaniu się z jej okowów. Mamy także poczucie drogi, jaką przeszliśmy w ostatnich latach, aby tak bardzo zbliżyć się do siebie [...]. Polityczna stabilność Litwy powinna zdecydować o jej przyjęciu do NATO, a jednym z dowodów tej stabilności jest coraz bliższa, więcej niż partnerska współpraca z Polską"23.

Partnerstwo w tym okresie obejmowało głównie współdziałanie na forum międzynarodowym i wspólne dążenie do strategicznych celów polityk zagranicznych obu państw, czyli członkostwa w strukturach europejskich i euroatlantyckich. W praktyce oznaczało to m.in. stałe polskie poparcie dla litewskiego członkostwa w NATO, mające postać instytucjonalną (np. wspólne ćwiczenia wojskowe) oraz polityczną (deklaracje polskich polityków na forum międzynarodowym). Ten drugi wymiar był szczególnie istotny w kontekście sprzeciwów Rosji wobec planów rozszerzania NATO na Wschód ${ }^{24}$.

21 Cyt. za: http://www.gintowt-dziewaltowski.elblag.pl.

22 Za „strategiczne partnerstwo” należy rozumieć taki stosunek między państwami, który przekracza typowy dla nich poziom współpracy międzynarodowej. Nie jest on jednak międzynarodowo upodmiotowionym prawnie związkiem państw; łączy partnerów równouprawnionych, jest określany specjalnym mianem i wyposażony w instytucję zdolną do wywierania wpływu na to partnerstwo. Zob. R. Stemplowski, Następny krok w strategicznym partnerstwie litewsko-polskim?, „Polski Przegląd Dyplomatyczny" 2001, t. 1, nr 2, s. 141-142. Por. K. Bałon, Co to jest partnerstwo strategiczne?, „Biuletyn PISM” 2001, nr 34.

$23 \mathrm{http}: / /$ www.kwasniewskialeksander.pl.

24 K. Korzeniewska-Wołek, Stosunki polsko-litewskie $w$ roku 2001, „Biuletyn PISM" 2002, nr 51. 
Obchodzona w 2001 r. rocznica 10-lecia wznowienia wzajemnych stosunków była okazją do podsumowań. W tym też roku dwukrotnie obradował Komitet Konsultacyjny przy Prezydentach Polski i Litwy, odbyły się dwie sesje Polsko-Litewskiego Zgromadzenia Poselskiego oraz zorganizowano Dni Kultury Litewskiej w Polsce ${ }^{25}$. W 2002 r. dynamika kontaktów nie osłabła, obejmują m.in. dwie robocze wizyty na Litwie prezydenta A. Kwaśniewskiego oraz trzy premiera L. Millera. Spotkania na najwyższych szczeblach odbywały się także w ramach inicjatyw multilateralnych, takich jak Sztokholmska Konferencja Bezpieczeństwa i Współpracy w Regionie Morza Bałtyckiego (w kwietniu) i konferencja prezydentów państw bałtyckich w Wilnie (w maju). Oficjalne wizyty na Litwie złożyli marszałkowie Sejmu i Senatu, odbyły się też dwie sesje wspólnego Zgromadzenia Poselskiego ${ }^{26}$. Podobnie częste spotkania miały miejsce również w latach następnych i stały się trwałym elementem strategicznego sojuszu obu państw.

W wyborach prezydenckich na Litwie w styczniu 2003 r. zwyciężył Rolandas Paksas, który bezpośrednio po ogłoszeniu wyników oświadczył, iż jego priorytetem pozostanie integracja z Unią Europejska i NATO oraz utrzymanie dobrych stosunków z państwami ościennymi. Określił relacje litewsko-polskie jako doskonałe, wyraził uznanie dla wsparcia, jakiego Polska udzieliła Litwie w jej dążeniu do członkostwa w NATO i zadeklarował wolę rozszerzania dalszych kontaktów ${ }^{27}$.

W roku następnym obchodzono 10-lecie podpisania traktatu między obu państwami, choć uroczystości z tym związane miały skromny charakter, m.in. z powodu kryzysu prezydenckiego na Litwie, związanego $\mathrm{z}$ odwołaniem R. Paksasa ${ }^{28}$. W ramach obchodów rocznicy zorganizowano

25 J. Stachura, Stosunki dwustronne Polski; Litwa, Łotwa, Estonia, „Rocznik Polskiej Polityki Zagranicznej 2002”, s. 273-275.

26 J. Stachura, Stosunki dwustronne Polski; Litwa, Łotwa, Estonia, „Rocznik Polskiej Polityki Zagranicznej 2003", s. 286-288.

27 A. Eberhardt, Wybory prezydenckie na Litwie - konsekwencje dla litewskiej polityki zagranicznej, „Biuletyn PISM” 2003, nr 3.

28 W październiku 2003 r. ujawniono raport służb specjalnych, w którym oskarżono najbliższych współpracowników prezydenta o kontakty z rosyjskim i litewskim światem przestępczym oraz rosyjskimi służbami specjalnymi. Zarzucono mu ponadto przyznanie litewskiego obywatelstwa rosyjskiemu biznesmenowi, w zamian za finansowanie kampanii wyborczej. Litewski Sejm wszczął procedurę impeachmentu, która zakończyła się usunięciem R. Paksasa z urzędu w kwietniu 2004 r. Zaplanowana na ten miesiąc wizyta prezydenta A. Kwaśniewskiego została więc odwołana. 
Dni Kultury Polskiej w Wilnie (w kwietniu) oraz festiwal „Wileńska Wiosna" w Warszawie (w maju). Podczas wielu spotkań podsumowano ostatnie 10 lat w stosunkach dwustronnych, oceniając je bardzo pozytywnie. Za niewątpliwy sukces uznano członkostwo Litwy w NATO od marca 2004 r. oraz wspólne wejście do Unii Europejskiej w maju 2004 r. W listopadzie 2005 r. pod koniec swojej prezydentury Aleksander Kwaśniewski spotkał się kolejny raz z prezydentem Valdasem Adamkusem w Sejnach i Druskiennikach, podkreślając tym samym znaczenie relacji polsko-litewskich. Nowo zaprzysiężony prezydent RP Lech Kaczyński złożył wizytę na Litwie w połowie marca $2006 \mathrm{r}^{29}{ }^{\mathrm{W}}$ tym też roku, w ramach obchodów 15 rocznicy nawiązania stosunków dyplomatycznych, zorganizowano m.in. Dni Polskich Miast i Festiwal Filmu Polskiego w Wilnie oraz Dni Litwy w Polsce, obejmujące ponad 120 imprez kulturalnych. Była to w tym czasie największa i najbardziej wszechstronna prezentacja osiagnięć artystycznych, kulturalnych, gospodarczych i turystycznych Litwy poza granicami kraju ${ }^{30}$.

Polsko-litewskie strategiczne partnerstwo weszło w nowy etap, którego głównym przesłaniem były próby uzgadniania i realizowania wspólnych celów na forum Unii Europejskiej, głównie współkształtowania jej wschodniej polityki w tym relacji z Rosją. Na przykład, Litwa poparła polskie weto $\mathrm{w}$ sprawie wznowienia rozmów nt. nowej umowy między Unią Europejską a Rosją w 2006 r., które wynikało z rosyjskiego embarga na handel polskim mięsem ${ }^{31}$. Podczas spotkania premierów Gediminasa Kirkilasa i Jarosława Kaczyńskiego w listopadzie 2006 r. $^{32}$, ten drugi określił postawę litewskiego partnera jako „więcej niż cenną” do-

W przedterminowych wyborach w czerwcu 2004 r. nowym prezydentem wybrany został V. Adamkus, który pierwszą oficjalną wizytę zagraniczną złożył właśnie w Polsce. Zob. J. Hyndle, M. Kutysz, Stosunki Polski z Litwa..., s. 146-149; Litwa - Paksas usunięty z urzędu, 6.04.2004 r., http://wyborcza.pl.

29 Warto zauważyć, iż prezydent L. Kaczyński po objęciu urzędu z pierwszą oficjalną wizytą zagraniczną udał się do Watykanu i Włoch, a Litwa była dopiero ósmym krajem który odwiedził. Fakt ten przyjęto w litewskich mediach z pewnym rozczarowaniem, jako symboliczny gest zerwania z tradycją zapoczątkowaną przez V. Adamkusa i A. Kwaśniewskiego.

30 Zob. Dni Litwy w Polsce, http://www.culture.pl.

31 Zob.: Walczymy o nasze prawa, „Dziennik” z 25-26.11.2006 r.; Wywalczona solidarność, „Dziennik” z 25-26.11.2006 r.

32 Warto dodać, że wkrótce po utworzeniu rządu premier G. Kirkilas udał się w lipcu 2006 r. w swoją pierwszą zagraniczną podróż właśnie do Warszawy. 
dając, że Polska i Litwa są „znakomitymi przyjaciółmi”33. W listopadzie 2007 r. został zaprzysiężony nowy polski rząd, którego premier Donald Tusk za główny cel polityki zagranicznej przyjął poprawę stosunków ze wszystkimi partnerami Polski, m.in. z Litwą i pozostałymi państwami bałtyckimi ${ }^{34}$. Po raz kolejny, za symboliczny gest uznano wybór Wilna jako miejsca jego pierwszej wizyty zagranicznej. Generalnie, rok 2007 obfitował w spotkania polityków obu krajów ${ }^{35}$, po 6 latach reaktywowano też prace Rady ds. Współpracy między Rządami Rzeczypospolitej Polskiej i Republiki Litewskiej ${ }^{36}$.

W kwietniu 2008 r. Litwa jako jedyne państwo członkowskie Unii zawetowała przyjęcie mandatu do rozpoczęcia negocjacji w sprawie nowej umowy o partnerstwie UE z Rosją. Zażądała, by mandat został rozszerzony o dodatkowe kwestie, które zapewniłyby uwzględnienie w przyszłych rozmowach z Rosją spraw leżących w interesie nie tylko Litwy, ale także pozostałych państw regionu. Dotyczyło to m.in. bezpieczeństwa energetycznego (przestrzegania przez Rosję Europejskiej Karty Energetycznej), wznowienia dostaw ropy rurociagiem Przyjaźn do rafinerii w Możejkach oraz zakończenia konfliktów w Gruzji i Mołdawii. Polska wyraziła swe zrozumienie dla postulatów litewskich, rozpoczynając jednocześnie intensywne konsultacje służące rozwiązaniu problemu ${ }^{37}$. Ostatecznie Litwa zgodziła się na uchylenie weta, o czym poinformowali czterej unijni ministrowie spraw zagranicznych (Polski, Litwy, Słowenii i Szwecji) na spotkaniu w Wilnie ${ }^{38}$.

33 Szef litewskiego rzqdu popiera polskie weto, „Dziennik” z 18.11.2006 r.

34 Zob. Expose premiera Donalda Tuska z 23.11.2007 r., http://www.rp.pl/arty$\mathrm{kul} / 71439 . \mathrm{html}$.

35 Na przykład, prezydent Polski złożył 3 wizyty na Litwie, a prezydent Litwy przebywał w Polsce aż 5-krotnie. W następnych latach intensywność wizyt nie spadła, w 2008 r. Lech Kaczyński odwiedzał Litwę 4-krotnie i również 4-krotnie w 2009 r., a w trakcie całej prezydentury złożył tam 16 wizyt, najwięcej spośród odwiedzanych krajów.

${ }^{36}$ H. Bukowiecka, Polityka Polski wobec Litwy, „Rocznik Polskiej Polityki Zagranicznej 2008", s. 204.

37 Polska znalazła się w dosyć niezręcznej sytuacji zapowiadając, że po spełnieniu swoich postulatów nie będzie blokowała negocjacji UE-Rosja. Z drugiej strony Litwa poparła wcześniejsze polskie weto i oczekiwała na podobny krok ze strony Polski. W przypadku wyraźnego poparcia stanowiska Litwy, Polska naraziłaby się na zarzut niewywiązywania się ze zobowiązań, a w sytuacji przeciwnej - na zarzut nielojalności wobec strategicznego partnera.

${ }^{38}$ H. Bukowiecka, Stanowisko Litwy wobec negocjacji porozumienia ramowego UE-Rosja, „Biuletyn PISM” 2008, nr 21; Litwa uchyla weto $w$ sprawie mandatu do negocjacji UE-Rosja, PAP z 11.05.2008 r. 


\section{Współpraca wojskowa}

Osobną i szczególnie istotną dziedziną współpracy są kwestie bezpieczeństwa i obronności. Oba państwa na początku lat 90. XX wieku stanęły przed koniecznością odnalezienia swojego miejsca w dynamicznie zmieniających się uwarunkowaniach bezpieczeństwa europejskiego i jak wspomniano, stosunkowo szybko za swój cel obrały członkostwo w NATO. W trakcie formułowania narodowych strategii bezpieczeństwa przyjęto, że polsko-litewska współpraca w dziedzinie obronności będzie pożądana. Służyć ma ona poszerzaniu strefy stabilności w Europie, co wynika m.in. z przesuwania granic NATO na wschód. Od chwili wejścia Polski do Paktu Północnoatlantyckiego stało się jasne, że droga Litwy do integracji euroatlantyckiej wiedzie przez Warszawę. Polska była najlepszym w tym zakresie promotorem Litwy, prowadząc w strukturach NATO probałtycki lobbing ${ }^{39}$.

Obok poparcia politycznego, zapoczątkowano także współpracę wojskową. Realizowano ją pierwotnie na podstawie Porozumienia między Ministrem Obrony RP i Ministrem Ochrony Kraju Republiki Litewskiej w sprawie ustanowienia dwustronnej wspótpracy z 15 czerwca 1993 r. Zostało ono uzupełnione Protokótem w sprawie ustanowienia dwustronnej wspótpracy wojskowej, dotyczacym wspótpracy w ramach „Partnerstwa dla Pokoju” z 12 maja 1995 r. Zawarto ponadto umowy dotyczące ochrony informacji niejawnych, tworzenia i rozbudowy zintegrowanego systemu kontroli powietrznej czy współpracy w dziedzinie wojskowego wykorzystania częstotliwości radiowych. Ważnym jej obszarem był wspólny udział w misjach pokojowych ONZ oraz wymiana doświadczeń szkoleniowych. Na przykład, litewscy oficerowie i podoficerowie mieli możliwość szkoleń w polskich uczelniach wojskowych, a polscy uczestniczyli w kursach języka litewskiego. W 1995 r. podpisano umowę o współpracy partnerskiej między Brygadą Piechoty Zmotoryzowanej „Żelazny Wilk” z Litewskich Sił Obronnych i 15 Warmińsko-Mazurską Dywizją Zmechanizowaną Wojska Polskiego im. Władysława Jagiełły. Strona polska pomagała litewskim siłom zbrojnym w procesie osiagania

39 B. Górka-Winter, Polsko-litewska współpraca $w$ dziedzinie bezpieczeństwa, „Polski Przegląd Dyplomatyczny” 2001, t. 1, nr 2, s. 127-128. Por. J. Kozakiewicz, Polityka..., s. 96-104. 
przez nie standardów natowskich, bezpłatnie dostarczyła też część sprzętu wojskowego i uzbrojenia ${ }^{40}$.

W dniu 5 lutego 2001 r. podpisano nową polsko-litewską umowę o współpracy w dziedzinie obronności. W jej art. 3 określono obszary kooperacji, m.in. takie jak: polityka obronna i strategia; funkcjonowanie sił zbrojnych w demokratycznym społeczeństwie; operacje wspierania pokoju; wsparcie logistyczne, szkolenie oraz polityka kadrowa i zarządzanie; rozwijanie interoperacyjności z NATO w narodowych siłach zbrojnych; rozwijanie systemów kontroli przestrzeni powietrznej i obrony powietrznej, wymiana informacji o sytuacji w przestrzeni powietrznej; zaopatrywanie w sprzęt i materiały pomocnicze itp. W art. 4 określono natomiast formy współpracy, jak: spotkania ministrów obrony, szefów sztabów i innych wyższych urzędników ministerstw obrony państw obydwu stron; coroczne konsultacje polityczno-wojskowe z udziałem przedstawicieli ministrów obrony i spraw zagranicznych; coroczne spotkania delegacji sztabów obrony/generalnych w celu wymiany informacji w zakresie rozwoju sił zbrojnych państw stron i określenia potrzeb w zakresie współpracy; konsultacje w zakresie bieżących kwestii związanych z integracją z NATO; wymiana doświadczeń między ekspertami; dwustronne ćwiczenia i szkolenia wojskowe oraz wspólne uczestnictwo w wojskowych ćwiczeniach międzynarodowych ${ }^{41}$.

Po wstapieniu Litwy do Paktu Północnoatlantyckiego w 2004 r. kontynuowano współpracę, m.in. w ramach wielonarodowych manewrów: „Baltic Challenge”, „Jackal Stone”, , „Wiatr Grunwaldu” po stronie pol-

40 Np. w 1993 r. przekazała 10 transporterów opancerzonych BRDM, a w 1996 r. 5 śmigłowców Mi-2 i 9 stacji radiolokacyjnych. Zob. A. Razma, G. Vilkelis, Polska i Litwa: poprzez wspólna historię do prawdziwego partnerstwa, w: Bezpieczeństwo Polski $w$ zmieniajacej się Europie. Miejsce Polski $w$ polityce bezpieczeństwa jej sqsiadów, red. P. Seydak, S. Helnarski, Warszawa-Toruń 1997, s. 132.

41 Umowa między Rzadem Rzeczypospolitej Polskiej a Rzadem Republiki Litewskiej dotyczaca wspótpracy $w$ dziedzinie obronności, sporzadzona $w$ Wilnie dnia 5 lutego 2001 r. (MP z dn. 5 lutego 2002 r.).

42 Są to największe ćwiczenia wojsk specjalnych w Europie. Pierwsza edycja o nazwie „Shamrock Key” odbyła się w 2006 r. na Litwie z udziałem żołnierzy z Polski, Litwy, Łotwy, Estonii i Norwegii. Kolejne organizowane są co roku, już pod kryptonimem „Jackal Stone” z udziałem żołnierzy z coraz większej liczby państw. W 2010 r. ćwiczenia realizowano na terenie Polski i Litwy, a ostatnie jak do tej pory w 2011 r. w Rumunii, Bułgarii i na Ukrainie. Brało w nich udział ponad 1,5 tys. żołnierzy wojsk specjalnych z 9 państw: Bułgarii, Chorwacji, Węgier, Litwy, Nor- 
skiej i „Amber Hope” po stronie litewskiej. Ostatnie edycje ćwiczeń „Amber Hope” miały miejsce w 2007 r. i 2011 r. Ich głównym celem było rozwijanie i doskonalenie współdziałania między państwami członkami NATO oraz uczestnikami programu „Partnerstwo dla Pokoju” w czasie prowadzenia przez nie wspólnych operacji. Oceniano też przygotowanie komponentów międzynarodowych do działania w rejonie misji. Brało w nich udział łącznie 10 państw z trzech kontynentów ${ }^{43}$.

Współpraca obejmuje wszystkie rodzaje sił zbrojnych, choć na szczególną uwagę zasługuje kooperacja sił morskich, także z innymi krajami leżącymi nad Bałtykiem. Od 1994 r. polskie siły morskie uczestniczyły we wszystkich przedsięwzięciach morskich organizowanych w ramach Programu „Partnerstwo dla Pokoju”, przygotowujących do współdziałania w ramach sił NATO. Od chwili wejścia Polski do Paktu Północnoatlantyckiego Marynarka Wojenna RP brała udział w ponad 300 międzynarodowych ćwiczeniach prowadzonych na morzu, powietrzu oraz lądzie. Na przykład, w czerwcu 2011 r. miały miejsce największe tego typu manewry na Bałtyku o kryptonimie „Baltops 2011”. Uczestniczyły w nich okręty z 13 państw, w tym z Polski i Litwy ${ }^{44}$.

W 1997 r. Polska przystapiła do powołanej z inicjatywy Danii międzynarodowej grupy koordynującej pomoc wojskową dla państw bałtyckich - BALTSEA, obejmującej także Litwę. Polska dążyła do intensyfikacji współdziałania w formułach „1+3” (Polska + Litwa, Łotwa, Estonia) i „3 + 3” (Polska, Dania, Niemcy + Litwa, Łotwa, Estonia). W ramach drugiej formuły otwarto biura oficerów łącznikowych Litwy, Łotwy i Estonii przy Korpusie Północno-Wschodnim w Szczecinie. Polska udzieliła Litwie pomocy w postaci dostaw sprzętu radiolokacyjnego i uzbrojenia, w ramach programu stworzenia bałtyckiego regionalnego systemu zarządzania przestrzenią powietrzną - BALTNET oraz zintegrowaniu go z systemem obserwacji przestrzeni powietrznej europejskiej części NATO ${ }^{45}$. Warto dodać, iż po wstąpieniu Litwy do Paktu

wegii, Polski, Rumunii, Ukrainy i Stanów Zjednoczonych. Zob. http://www.mon.gov.pl/ $\mathrm{pl} /$ artykul/11873.

${ }_{43}$ Swoje jednostki wystawiły: Armenia, Polska, Litwa, Łotwa, Estonia, Finlandia, Niemcy, Wielka Brytania, USA i Kanada, natomiast Białoruś, Gruzja, Mołdawia i Rosja wysłały obserwatorów; http://www.army.mil.pl; http://kariuomene.kam.lt.

${ }_{44} \mathrm{http}: / /$ www.wojsko-polskie.pl/aktualnosci/17244,manewry-baltops-2011.html.

45 J. Stachura, Stosunki dwustronne Polski; Litwa, Lotwa, Estonia, „Rocznik Polskiej Polityki Zagranicznej 2003”, s. 288-289. 
Północnoatlantyckiego, wobec braku własnych samolotów bojowych, państwa sojusznicze rozpoczęły patrolowanie litewskiej (oraz łotewskiej i estońskiej) przestrzeni powietrznej, w systemie 3-4 miesięcznych rotacji. W ramach misji „Baltic Air Policing” zadanie to wypełniały także polskie siły powietrzne z Kontyngentu Wojskowego „Orlik” (w latach 2006, 2008 i 2010) ${ }^{46}$.

Wymiernym efektem współpracy wojsk lądowych było powołanie polsko-litewskiego batalionu sił pokojowych LITPOLBAT. Z inicjatywą jego utworzenia wystapił Prezydent Litwy Algirdas Brazauskas w czasie wizyty w Polsce w lutym 1995 r. Dwa lata później powołano sztaby batalionu, a od 1998 r. rozpoczęto szkolenie jego narodowych elementów składowych oraz ich zgrywanie. W 1999 r. batalion osiągnął pełną zdolność do działań operacyjnych. Formacja ta przeznaczona była do utrzymania i przywracania międzynarodowego pokoju i bezpieczeństwa, poprzez udział w misjach pokojowych, akcjach humanitarnych i ratowniczych. Warto dodać, iż do 2004 r., czyli momentu wstapienia Litwy do Paktu, była to jedyna formacja składająca się z sił członka NATO i kraju aspirującego. Żołnierze LITPOLBAT pełnili służbę w pokojowych misjach w Kosowie, Syrii i Libanie. W czerwcu 2008 r. batalion został rozformowany ${ }^{47}$. Litewscy żołnierze wchodzili w skład polskich kontyngentów w Iraku ${ }^{48}$ oraz w Afganistanie ${ }^{49}$.

\section{Współpraca energetyczna}

Kwestie bezpieczeństwa energetycznego Polski i Litwy są ściśle związane z ich wspólnym wschodnim sąsiadem, czyli Rosją. W tym kontekście Polska, przy wsparciu Litwy, podjęła wysiłek przekonania pozostałych państw Unii Europejskiej do solidarności energetycznej, stworzenia mechanizmów wzajemnych gwarancji bezpieczeństwa oraz

46 http://www.airpolicing.wp.mil.pl; http://www.sp.mil.pl.

47 http://www.mon.gov.pl.

48 Liczba wojska wysyłanego na misje jest proporcjonalna do liczby ludności i możliwości danego państwa. Np. według stanu na 9.12.2003 r. Polska miała zaangażowanych w Iraku 2400 żołnierzy a Litwa 105. Zob. Europa Środkowa - rok przełomów, „Rocznik Strategiczny 2003/2004”, Warszawa 2004, s. 239.

49 Pod koniec 2011 r. siły ISAF w Afganistanie liczyły łącznie ok. 130 tys. żołnierzy i pracowników wojska z 48 krajów, z tego prawie 2600 żołnierzy z Polski i ok. 200 z Litwy. Zob. http://www.isaf.wp.mil.pl. 
wykreowania wspólnej polityki energetycznej. W polskim stanowisku zaprezentowanym podczas szczytu Rady Europejskiej w marcu 2006 r., jako priorytetowe określono trzy kwestie: dywersyfikację dostaw energii i gazu, zasadę solidarności oraz spójności zewnętrznej polityki energetycznej UE. W debacie nad polityką energetyczną dla Europy Polska zgłosiła szereg postulatów, m.in. utworzenie wymiaru energetycznego Europejskiej Polityki Sąsiedztwa, stworzenie specjalnego Europejskiego Traktatu Bezpieczeństwa Energetycznego oraz przede wszystkim wypracowanie wspólnego scenariusza działań w sytuacjach kryzysowych, bazującego na zasadzie solidarności ${ }^{50}$.

Problem bezpieczeństwa energetycznego zdominował relacje polsko-litewskie w okresie prezydentury Lecha Kaczyńskiego. Z jego inicjatywy zorganizowano w maju 2007 r. w Krakowie szczyt energetyczny, z udziałem liderów Polski, Litwy, Ukrainy, Gruzji i Azerbejdżanu. Rozmowy dotyczyły m.in. planów importu ropy z kierunku południowo-wschodniego, przez Ukrainę do Polski i dalej w kierunku Niemiec oraz planów przedłużenia ropociągu Odessa-Brody do Gdańska. We wspólnej deklaracji kończącej spotkanie była mowa m.in. o konieczności powołania grupy rządowej na szczeblu odpowiednich ministerstw, która opracuje szczegóły przyszłego międzyrządowego porozumienia w tej sprawie ${ }^{51}$.

Prezydent L. Kaczyński był gorącym zwolennikiem budowy mostu energetycznego między Litwą a Polską, stanowiącego część „pierścienia energetycznego" oplatającego kraje leżące nad Bałtykiem. Dzięki połączeniu systemu energetycznego z systemami innych krajów, Polska mogłaby liczyć na wsparcie z zagranicy np. w razie awarii elektrowni lub niedoborów energii. Dla obu krajów most ten byłby też formą uniezależnienia się od dostaw energii z kierunku rosyjskiego ${ }^{52}$. Inicjatywa ta wpisuje się także - zgodnie z unijnymi dyrektywami - w tworzenie transgranicznej wymiany energii, by zapewnić rozwój wewnętrznego

50 M. Banat-Adamiuk, Aktywność Polski w Unii Europejskiej, „Rocznik Polskiej Polityki Zagranicznej 2007”, s. 50-54.

51 Podobne szczyty $\mathrm{z}$ udziałem prezydentów organizowano cyklicznie, m.in. w październiku 2007 r. w Wilnie, maju 2008 r. w Kijowie oraz w listopadzie 2008 r. w Baku. Zob. Prezydencki szczyt energetyczny w Krakowie, http://www.prezydent.pl; Komunikat z krakowskiego spotkania Prezydentów w sprawie wspótpracy energetycznej, http://www.mg.gov.pl.

52 P. Przybylski, Polska i Litwa połaczq się mostem energetycznym, „Dziennik” z 10.10.2007 r.; A. Słojewska, Bruksela naciska na budowę mostu energetycznego, „Rzeczpospolita” z 1.12.2007 r. 
rynku energetycznego w UE. Po trwających 16 lat rozmowach, w lutym 2008 r. podpisano polsko-litewską umowę o powołaniu spółki LitPol Link, która zajmie się budową mostu energetycznego łączącego polski Ełk i litewski Alytus, a zakończenie realizacji inwestycji zaplanowano na rok $2015^{53}$.

Kolejnym elementem tworzenia bezpieczeństwa energetycznego są plany wspólnej budowy elektrowni atomowej na Litwie w Visaginas, w które zaangażowane są także Estonia i Łotwa. Nowa elektrownia ma powstać w miejsce likwidowanej Ignalińskiej Elektrowni Atomowej, bowiem Litwa wstępując do UE zobowiązała się zamknąć tamtejszy blok typu czarnobylskiego ${ }^{54}$. Wspólny regionalny projekt elektrowni jądrowej dałby możliwość harmonizacji działań w zakresie bezpieczeństwa energetycznego. Polska natomiast uzyskałaby; po pierwsze - stabilne źródło energii o istotnym znaczeniu głównie dla jej północno-wschodnich regionów, po drugie - doświadczenie, ważne z uwagi na własne plany atomowe. Ostatnie lata pokazały jednak, że coraz więcej czynników utrudnia realizację projektu w Visaginas, m.in. niesprzyjające uwarunkowania zewnętrzne (budowa elektrowni w Obwodzie Kaliningradzkim i na Białorusi) oraz konsekwencje katastrofy w japońskiej Fukushimie w 2011 r. Konkurencyjność programu atomowego na Litwie zależy także od budowy połączeń elektroenergetycznych tego kraju z Polską i Szwecją ${ }^{55}$. W grudniu 2011 r. Litwa podpisała z japońskim koncernem Hitachi porozumienie w sprawie podstawowych warunków umowy koncesyjnej. Większość udziałów w przedsięwzięciu ma mieć inwestor strategiczny, 34 proc. ma przypaść Litwie, pozostałą część mieli podzielić między sobą partnerzy regionalni - spółki energetyczne z Polski, Estonii i Łotwy. Na początku grudnia 2011 r. Polska Grupa Energetyczna zawiesiła jednak zaangażowanie w ten projekt ${ }^{56}$.

Podobnie nie do końca udanym przedsięwzięciem we wzajemnych relacjach jest zakup w 2006 r. przez Polski Koncern Naftowy „Orlen” litewskiej rafinerii w Możejkach. Zainteresowane rafinerią były także firmy rosyjskie, mocno wspierane przez ich rząd, jednak polska oferta była najkorzystniejsza. W odpowiedzi strona rosyjska przerwała dostawy

53 Most energetyczny połaczy nas z Litwa, 12.02.2008 r. http://news.money.pl; http://www.mg.gov.pl/node/15137; http://www.litpol-link.com/pl.

54 D. Szyller, Polska wybuduje elektrownię atomowa, ,Dziennik” z 28.06.2007 r.

55 K. Dudzińska, Elektrownia atomowa na Litwie, „Biuletyn PISM” 2011, nr 78.

56 Elektrownia atomowa na Litwie bez Polski, http://kurierwilenski.lt. 
ropy do Możejek ${ }^{57}$, ponadto spłonęła jedna z kluczowych instalacji w rafinerii, co spowodowało spore kłopoty finansowe firmy, spadek obrotów i konieczność transportowania ropy statkami, m.in. z Wenezueli. Rentowność inwestycji próbowano ratować zakupem terminalu naftowego w Kłajpedzie, co zapewniłoby ciagłość dostaw surowca do rafinerii oraz sprzedaż jej produktów. Jednak Litwa odrzuciła polską propozycję, uznając terminal za przedsiębiorstwo o strategicznym znaczeniu dla państwa. Ostatecznie w 2011 r. PKN Orlen ogłosił chęć sprzedaży 100\% udziałów w AB Orlen Lietuva. Na liście chętnych do kupienia Możejek wymienia się przede wszystkim spółki rosyjskie, m.in. Rosnieft i Łukoil.

Komentując całą sytuację, można zaryzykować stwierdzenie o politycznych motywach całego przedsięwzięcia. Transakcję mocno wspierał ówczesny polski rząd, mający uprzywilejowany pakiet akcji PKN Orlen, a projekt wykorzystano w grze ze stroną rosyjską. Przyznał to minister spraw zagranicznych Radosław Sikorski mówiąc: „Podjęliśmy się największej inwestycji w historii naszego państwa odnośnie rafinerii w Możejkach. I ta inwestycja wynikła w znacznej mierze z intencji politycznych. Lech Kaczyński ze względu na przyjaźń względem Litwy nakłonił naszą spółkę do zapłacenia ceny, która, jak obecnie wszyscy przyznają, była za wysoka" ${ }^{, 58}$. Były prezes PKN Orlen ocenia to następująco: „Pomysł narodził się jako projekt czysto biznesowy, ale ostatecznie na transakcję miały wpływ zarówno czynniki biznesowe, jak i polityczne [...].Wyglądało, że Możejki będą katalizatorem współpracy w dziedzinie gospodarczej. To za sprawą transakcji Orlenu w agendzie rozmów pojawiło się wiele innych projektów polsko-litewskich. Wyda-

57 Warto dodać, iż litewski zakład w 1998 r. kupili Amerykanie z koncernu Williams, na co strona rosyjska odpowiedziała także cyklicznym wstrzymywaniem dostaw ropy. Ostatecznie Amerykanie postanowili wycofać się z tej inwestycji, a nowym właścicielem rafinerii stał się rosyjski koncern Jukos. Gdy jego najwięksi akcjonariusze z prezesem Michaiłem Chodorkowskim na czele, znaleźli się na celowniku Kremla, pod pretekstem zaległości podatkowych spółka została praktycznie doprowadzona do bankructwa i przejęta przez rosyjskie władze. Tak się jednak nie stało z Możejkami, bowiem właścicielem akcji była zarejestrowana w Holandii spółka zależna Jukosu. Po miesiącach batalii sądowych Rosjanom nie udało się zablokować sprzedaży Możejek. PKN Orlen kupił 53\% akcji od Jukosu oraz w dwóch transzach pozostałe akcje od rządu Litwy za łączną kwotę ponad 2,7 mld dol. Była to w tym czasie największa polska inwestycja zagraniczna. Zob. D. Malinowski, Orlen: zakup Możejek to odważna decyzja obarczona ryzykiem, http://www.wnp.pl; A. Grzeszak, Oblężenie Możejek, http://www.polityka.pl.

58 http://www.wilno.polemb.net/gallery/i/pl/Wywiad\%20Sikorskiego.pdf. 
wało się, że wszystko ruszy z kopyta: elektrownia atomowa Ignalina, most energetyczny, infrastruktura drogowa Via Baltica. I gdzieś to się wszystko załamało" ${ }^{99}$. Natomiast obecny prezes polskiego koncernu stwierdził wprost: „To była zła, nietrafiona, niepotrzebna krajowi inwestycja”60.

\section{Pogorszenie wzajemnych relacji}

W ostatnim okresie nierozwiązane od wielu lat problemy coraz wyraźniej utrudniają wzajemne relacje i jak się wydaje, strony powoli tracą $\mathrm{w}$ tej kwestii cierpliwość ${ }^{61}$. Jedną ze spraw spornych jest posługiwanie się językiem ojczystym w kraju zamieszkania. Już w 1994 r. w traktacie międzypaństwowym $\mathrm{w}$ jego art. 14 zapisano prawo do ,swobodnego posługiwania się językiem mniejszości narodowej w życiu prywatnym i publicznie” oraz „używania swych imion i nazwisk w brzmieniu języka mniejszości narodowej”, a w art. 15 strony „rozważą dopuszczenie używania języków mniejszości narodowych przed swymi urzędami, szczególnie zaś w tych jednostkach administracyjno-terytorialnych, w których dużą część ludności stanowi mniejszość narodowa"62. W praktyce Litwa nie zgadza się na obecność języka polskiego w życiu publicznym np. w urzędach, a nazwy miejscowości i ulic (poza nielicznymi wyjątkami)

59 Oblężenie Możejek. Rozmowa z Igorem Chalupcem, bytym prezesem PKN Orlen, o tym jak z największej polskiej inwestycji zrobił się największy problem płockiego koncernu, http://www.polityka.pl/rynek/gospodarka/1500417,1,mozejki-wielka-pomylka-orlenu.read.

60 Cyt. za: A. Kubik, Orlen: sprzedaż Możejek, koniec Bliskich, kupno złóż, http://wyborcza.biz.

61 Jak określił to prezydent Bronisław Komorowski: „Rzeczą trudną do zrozumienia dla Polaków - jak również dla polskiej polityki - jest to, że od ponad dziesięciu lat nie możemy się doczekać wykonania traktatu polsko-litewskiego z 1994 roku”. Cyt za: Komorowski: Są nierozwiązane sprawy między Polską Litwą, PAP z 16.02.2011 r. Szef polskiej dyplomacji Radosław Sikorski w wywiadzie dla dziennika „Lietuvos Rytas określił to następująco: „Polska jest zawiedziona tym, że w ciagu dwudziestu lat Litwa nie rozwiązała żadnego problemu zgłaszanego przez mniejszość polską". Cyt. za: Sikorski: Litwa zawodzi Polskę, PAP z 22.07.2011 r. Natomiast szef litewskiego MSZ Audronius Ażubalis ocenił: „Stosunki polsko-litewskie są dobre, ale niedobre jest podłoże emocjonalne tych stosunków”. Zob. Szef litewskiego MSZ: stosunki polsko-litewskie sq dobre, PAP z 17.01.2012 r.

62 Traktat między Rzeczapospolita Polskq a Republika Litewskq o przyjaznych stosunkach i dobrosqsiedzkiej wspótpracy..., http://isap.sejm.gov.pl. 
nie mogą być używane jednocześnie w dwóch językach (litewskim i polskim), gdyż grożą za to kary finansowe. Zabrania też pisowni polskich nazwisk w ich oryginalnym brzmieniu, są one przymusowo lituanizowane. Stan ten uznały zarówno Litewska Państwowa Inspekcja Językowa, jak i tamtejszy parlament w 2010 r. powołując się na litewską konstytucję $^{63}$. Polacy uważają, że stoi to w sprzeczności z duchem polsko-litewskiego traktatu z 1994 r. oraz stanowi naruszenie konwencji Rady Europy o ochronie mniejszości narodowych ${ }^{64}$.

W 2011 r. przyjęto na Litwie nową ustawę o oświacie, która w ocenie litewskich Polaków jest dyskryminująca ${ }^{65}$. Zgodnie z proponowaną przez Litwinów regulacją nawet w szkołach mniejszości narodowych lekcje historii i geografii Litwy oraz wiedzy o świecie w części dotyczącej tego kraju mają być prowadzone po litewsku. Istnieje tym samym niebezpieczeństwo, iż ze szkół stopniowo będą znikać przedmioty nauczane w językach mniejszości narodowych. Ustawa zakłada również, że na maturze jako język podstawowy trzeba będzie zdawać język litewski, co może utrudniać młodzieży pochodzenia polskiego dostanie się na studia. Litewscy Polacy twierdzą, że założenia ustawy naruszają zasady równouprawnienia oraz że jest to początek końca polskich szkół na Litwie ${ }^{66}$. W reakcji na protesty społeczności polskiej przeciwko zapisom znowelizowanej ustawy o oświacie, polskie MSZ wydało stosowne oświadczenia $^{67}$, a premier Donald Tusk złożył roboczą wizytę w Wilnie.

63 Parlament odrzucił projekt liberalizujący zasady pisowni imion i nazwisk 8 kwietnia 2010 r., akurat w dniu, w którym swoją wizytę w Wilnie składał prezydent Lech Kaczyński.

64 J. Pawlicki, Koniec partnerskich iluzji, 16.02.2011, http://wyborcza.pl; Radczenko: Jeszcze raz o polskich szkołach $w$ Wilnie, 14.12.2011 r., http://politykawschodnia.pl.

65 Zgodnie z nowym prawem w szkołach litewskich i szkołach mniejszości narodowych egzamin maturalny z języka litewskiego zostanie ujednolicony. Obecnie program nauczania litewskiego w szkołach litewskich i nielitewskich na Litwie różni się. W szkołach litewskich język ten jest wykładany jako język ojczysty, a więc w szerszym wymiarze, natomiast w szkołach mniejszości - jako język państwowy, w wymiarze ograniczonym. W całości po litewsku wykładany jest przedmiot: podstawy wychowania patriotycznego.

66 A. Mazurczyk, Czy na pewno jest dobrze? Napięte stosunki polsko-litewskie, http://www.polityka.pl.

67 Oświadczenie Ministerstwa Spraw Zagranicznych $w$ zwiazku z przyjęciem przez Sejm RL ustawy oświatowej w dniu 17 marca 2011 r.; Oświadczenie Ministerstwa Spraw Zagranicznych w zwiazku z podpisaniem przez Prezydent Republiki Litewskiej ustawy o oświacie w dniu 30 marca 2011 r., http://www.msz.gov.pl. 
We wrześniu 2011 r. powołano Polsko-Litewski Zespół Ekspertów Edukacyjnych i Przedstawicieli Mniejszości Narodowych, który miał rozwiązać ten problem. Pomimo pięciu spotkań zespołu, nie udało się osiagnnąc żadnego porozumienia, nie było kompromisu nawet w kwestii opracowania wspólnego komunikatu końcowego ${ }^{68}$.

Wyzwaniem na przyszłość jest także kilka innych problemów, m.in. Litwa ma zastrzeżenia dotyczące zaopatrzenia w podręczniki szkół litewskich w Polsce, szczupłości czasu antenowego i zasięgu emisji polskich programów radiowych w języku litewskim oraz wprowadzenia Karty Polaka, wydawanej naszym rodakom mieszkającym poza granicami kraju. Polska mniejszość na Litwie nie czuje się usatysfakcjonowana swoim statusem, podkreślając trudności związane ze zwrotem ziemi Polakom mieszkającym na Wileńszczyźnie czy istnieniem progu wyborczego dla mniejszości w wyborach do Sejmasu ${ }^{69}$.

Podejmuje się próby odbudowy przyjaznych relacji poprzez powoływanie wspólnych organów, co nie daje jednak gwarancji rozwiązania problemów. Inne działania mają charakter symboliczny, na przykład spotkanie prezydenta - elekta Bronisława Komorowskiego z prezydent Litwy Dalią Grybauskaite w lipcu 2010 r. z okazji 600. rocznicy bitwy pod Grunwaldem oraz pierwsza zagraniczna wizyta B. Komorowskiego, tuż po zaprzysiężeniu, złożona właśnie na Litwie. Obecny stan relacji polsko-litewskich pokazała 20 rocznica nawiązania stosunków dyplomatycznych obchodzona w 2011 r., która miała skromny charakter i przeszła w zasadzie niezauważona ${ }^{70}$.

${ }^{68} \mathrm{Z}$ uwagi na rozbieżność stanowisk strony postanowiły wydać odrębne oświadczenia w tym zakresie. Zob. Piqte posiedzenie Polsko-Litewskiego Zespotu Ekspertów Edukacyjnych i Przedstawicieli Mniejszości Narodowych w Trokach, http://www.men.gov.pl.

${ }^{69}$ Do połowy lat 90. XX w. progi wyborcze nie obejmowały partii reprezentujących mniejszości narodowe. Po ich wprowadzeniu znacznie zmniejszyła się liczba posłów w Sejmasie Akcji Wyborczej Polaków na Litwie. Na przykład, w wyborach w październiku 2008 r. AWP nie przekroczyła 5\% progu wyborczego w systemie proporcjonalnych zdobywając 4,79\% głosów i obsadziła jedynie 3 mandaty w okręgach jednomandatowych. Sprawa wprowadzenia progów dla mniejszości narodowych była przedmiotem kilku interpelacji poselskich w polskim Sejmie. Zob. http://orka2.sejm.gov.pl/IZ6.nsf/main/6B9AB684. Por. S. Tarasiewicz, Znowu okroja , polskie” okręgi wyborcze, http://kurierwilenski.lt.

${ }^{70} \mathrm{~W}$ odróżnieniu od 15. rocznicy w 2006 r., kiedy to przypomnijmy, zorganizowano wiele imprez m.in. Dni Litwy w Polsce pod honorowym patronatem prezydentów obu państw. 


\section{Współpraca transgraniczna i międzyregionalna}

Pogorszenie stosunków politycznych w ostatnich latach nie przełożyło się na współpracę na wspólnym pograniczu, a wstąpienie obu krajów do Unii Europejskiej dało nowe możliwości w sferze kooperacji transgranicznej, wynikające m.in. z charakteru wewnątrzunijnej granicy. Aktywność na pograniczu polsko-litewskim rozwinęła się jednak wcześniej. Już w Traktacie między Rzeczapospolita Polska a Republika Litewska o przyjaznych stosunkach $i$ dobrosqsiedzkiej wspótpracy w art. 10 zapisano: „Układające się Strony przywiązują duże znaczenie do wzajemnie korzystnej współpracy między gminami, miastami i innymi jednostkami administracyjno-terytorialnymi oraz regionami, w szczególności na obszarach przygranicznych. Strony będą ułatwiać i popierać tę współpracę we wszystkich dziedzinach"71.

Jej podstawę instytucjonalną wyznacza Umowa między Rządem Rzeczypospolitej Polskiej a Rzq̨em Republiki Litewskiej o wspótpracy transgranicznej, podpisana w Wilnie 16 września 1995 r. Zauważono w niej, iż współpraca tego typu pozytywnie wpływa na zacieśnienie stosunków między obu państwami. Utworzono Polsko-Litewską Komisję Międzyrządową do spraw Współpracy Transgranicznej, której głównym celem jest wspieranie związków transgranicznych, poprzez stwarzanie sprzyjających warunków, rozwiązywanie problemów oraz koordynację aktywności podejmowanej przez władze regionalne i lokalne $^{72}$.

Współpracę partnerską realizują miasta i gminy oraz samorządy wojewódzkie, m.in. w ramach działającego od 1998 r. Polsko-Litewskiego Forum Samorządowego. Na przykład, województwo warmińsko-mazurskie podpisało umowę z Okręgiem Taurogi w listopadzie 2004 r., a w październiku 2008 r. został otwarty w Olsztynie Honorowy Konsulat Republiki Litewskiej. Jego utworzenie wynikało z rosnących

71 Zob. Traktat między Rzeczapospolita Polskq a Republika Litewskq o przyjaznych stosunkach i dobrosasiedzkiej wspótpracy, sporzadzony w Wilnie dnia 26 kwietnia 1994 r. (Dz. U. 1995, Nr 15, poz. 71), http://isap.sejm.gov.pl.

${ }^{72}$ Zob. Umowa między Rzqdem Rzeczypospolitej Polskiej a Rzadem Republiki Litewskiej o wspólpracy transgranicznej, podpisana $w$ Wilnie $w$ dniu 16 września 1995 r., w: A. Przyborowska-Klimczak, W. Staszewski, Stosunki traktatowe Polski z państwami sqsiednimi. Wybór dokumentów, Lublin 1998, s. 239-242. 
powiązań gospodarczych, społecznych oraz naukowych Warmii i Mazur z Litwą ${ }^{73}$.

Niemal co ósma polska gmina ma partnera na Litwie. Dotyczy to głównie gmin z północno-wschodniej Polski, a najwięcej związków zawarły samorządy Podlasia. Co druga gmina $\mathrm{z}$ tego województwa oraz co trzecia z warmińsko-mazurskiego i pomorskiego współpracuje z jakimś samorządem litewskim. W skali kraju Litwa zajmuje szóste miejsce wśród państw, z których samorządami najczęściej współpracują polskie gminy $^{74}$. Na przykład, Suwałki i Ostrołęka kooperują z litewskim Alytusem, Mikołajki z Varenie, a Częstochowa i Białystok z Wilnem. Szczególnie intensywną współpracę prowadzą polskie gminy nadgraniczne Sejny i Puńsk, głównie poprzez związki i stowarzyszenia mniejszości narodowych. We wzajemnych kontaktach przeważa wymiana młodzieży szkolnej oraz przedstawicieli placówek oświatowych, a także wspólnie organizowane imprezy kulturalne $\mathrm{e}^{75}$. Na wspólnym pograniczu działają od wielu już lat euroregiony: Niemen (z udziałem partnerów z Rosji i Białorusi) ${ }^{76}$ i Bałtyk (zrzeszający również samorządy z Danii, Szwecji i Rosji) ${ }^{77}$.

Kontakty regionów przygranicznych stymulują ich rozwój, sprzyjają też lepszemu poznaniu oraz przezwyciężaniu nieufności i uprzedzeń między środowiskami lokalnymi ${ }^{78}$. Znaczący jest w tym udział organizacji pozarządowych. Spośród wielu wymienić można Ogólnopolski Klub Miłośników Litwy, Stowarzyszenie Polska-Litwa czy założony w 1991 r. Ośrodek „Pogranicze Sztuk - Kultur - Narodów” z siedzibą w Sejnach ${ }^{79}$. W innych sferach aktywności, od kilku lat z powodzeniem

${ }^{73} \mathrm{Na}$ przykład, Uniwersytet Warmińsko-Mazurski od wielu lat współpracuje ze stroną litewska, a otwarciu Konsulatu towarzyszyło podpisanie porozumienia o współpracy pomiędzy UWM a Instytutem Historii Litwy. Zob. Będzie honorowy konsulat Litwy w Olsztynie, 22.10.2008 r., http://www.olsztyn24.com.

${ }^{74}$ A. Skorupska, Wspótpraca międzynarodowa samorzadu gminnego na podstawie badań, w: Wspótpraca międzynarodowa samorzadu gminnego - Raporty, Warszawa 2005, s. 26.

${ }^{75}$ M. Proniewski, Wpływ granicy $i$ wspótpracy transgranicznej na rozwój regionalny i lokalny regionu pótnocno-wschodniego, w: Rola granicy $i$ wspótpracy transgranicznej w rozwoju regionalnym i lokalnym, red. A. Mync, R. Szul, Warszawa 1999, s. 121-126.

${ }^{76} \mathrm{http}: / /$ www.niemen.org.pl.

$77 \mathrm{http}: / /$ www.eurobalt.org.pl.

78 Szerzej: Pogranicze polsko-litewskie - aktywizacja wspótpracy, red. W. Misiak, A. Rejzner, Warszawa 2002.

${ }^{79}$ Zob. http://www.pogranicze.sejny.pl. 
działa Polsko-Litewska Izba Turystyki i Dziedzictwa Kulturowego ${ }^{80}$ czy Polsko-Litewska Izba Gospodarcza Rynków Wschodnich ${ }^{81}$.

Współpraca regionalna jest integralną częścią polityki zagranicznej obu państw w aspekcie dwustronnym, jak i wielostronnym. Polska i Litwa współpracują m.in. na forum Rady Państw Morza Bałtyckiego oraz w grupach roboczych powoływanych przez tę organizację. Do zacieśnienia kontaktów regionalnych przyczynia się Wymiar Północny Unii Europejskiej, w którego ramach realizowane są m.in. programy szkoleniowe dla służb granicznych, administracji publicznej oraz przedsiębiorców z obu państw. Współpraca ta służy tworzeniu wokół Morza Bałtyckiego obszaru przyjaznego sąsiedztwa oraz wypracowaniu takich instrumentów politycznych, dzięki którym będzie możliwe utrzymanie stabilności w tej części kontynentu. Zaangażowanie w tę inicjatywę dało Polsce i Litwie nowe możliwości kształtowania stosunków z Federacją Rosyjską i łagodzenia jej obaw związanych z rozszerzaniem struktur europejskich i euroatlantyckich. Oba kraje są również żywo zainteresowane przyszłością Obwodu Kaliningradzkiego FR - wewnątrznatowskiej i wewnątrzunijnej enklawy, z którą bezpośrednio graniczą ${ }^{82}$.

\section{Uwagi końcowe}

Dokonując bilansu ostatnich 20 lat wzajemnych stosunków trudno o ich jednoznaczną ocenę. Pierwsza dekada to okres poszukiwania i wypracowywania rozwiązań służących realizacji zbieżnych celów polityk zagranicznych obu państw. Widoczne było wzajemne poparcie w dąże-

${ }^{80}$ Jest to organizacja samorządowa podmiotów działających w zakresie turystyki z Polski i Litwy, z siedzibą po stronie polskiej w Sejnach, a po stronie litewskiej w Lazdijai. Jej głównych celem jest wspieranie i rozwijanie turystyki w Polsce, na Litwie i w krajach trzecich, ze szczególnym uwzględnieniem agroturystyki oraz ożywienie wymiany turystycznej między Polską a Litwą. Zob. http://www.powiat.sejny.pl/plitidk.html.

${ }_{81}$ Zob. http://www.wigry.win.pl/plig.htm oraz M. Runiewicz, Rola organizacji pozarzqdowych (NGO) we wspótpracy transgranicznej Polski z sqsiadami pótnocno-wschodnimi, w: Wspótpraca transgraniczna Polski..., s. 118-129.

82 Problem funkcjonowania Obwodu po rozszerzeniu NATO i UE o Polskę i Litwę istotnie wpływał na kształtowanie relacji z Rosją. Zob. Polska wobec Obwodu Kaliningradzkiego Federacji Rosyjskiej, red. A. Żukowski, Olsztyn 2004; T. Valionis, Przyszłość współpracy Litwy i Polski z Obwodem Kaliningradzkim w kontekście rozszerzenia Unii Europejskiej, w: Poziomy aktywności Polski w środowisku międzynarodowym, red. T. Łoś-Nowak, A. Dudek, Legnica 2002, s. 257-259. 
niu do członkostwa w NATO i Unii Europejskiej, co przerodziło się w szczególnie intensywne relacje określane mianem strategicznego partnerstwa. Ukształtowano sieć współpracy, obejmującą kontakty we wszystkich w zasadzie dziedzinach i na wszystkich szczeblach. Zinstytucjonalizowano formy współpracy poprzez utworzenie m.in.: Komitetu Konsultacyjnego przy Prezydentach Polski i Litwy, Polsko-Litewskiego Zgromadzenia Poselskiego czy Rady ds. Współpracy między Rządami Rzeczypospolitej Polskiej i Republiki Litewskiej. Jako sukces drugiej dekady polsko-litewskich relacji można uznać stopniową zmianę wzajemnego postrzegania przez pryzmat historii i spornych kwestii z niej wynikających. Dostrzeżenie znaczenia wzajemnej współpracy dla stabilizacji w regionie Europy Środkowej i Wschodniej oraz wyznaczenie jej zakresu w procesie integracji z UE i NATO pozwoliło częściowo przełamać pochodzące z przeszłości uprzedzenia i w tym kontekście były to lata wykorzystanej szansy.

Końcówka drugiego dziesięciolecia pokazała jednak, że nierozwiązane problemy związane głównie ze statusem polskiej mniejszości na Litwie stanowią swoisty klincz we wzajemnych kontaktach. Pogłębia go negatywna reakcja strony litewskiej na naturalną presję Polski celem poprawy położenia jej mniejszości oraz udzielane jej wsparcie. Jak się wydaje, drogą donikąd jest widoczne ostatnio porzucenie wyznawanej przez cały analizowany okres polityki mozolnego budowania dobrosąsiedzkich relacji pomiędzy Warszawą i Wilnem i rozpatrywanie wzajemnych stosunków przez pryzmat mniejszości. Należy nadal konsekwentnie, mimo trudności, krok po kroku próbować rozwiązywać zadawnione problemy, realizować korzystne dla obu stron projekty (np. transgraniczne), wyciszając jednocześnie negatywne emocje. Trzeba spróbować dotrzeć do litewskiej opinii publicznej, podjąć wysiłek wykreowania pozytywnego wizerunku Polski na Litwie, a w rezultacie zmiany jej postrzegania przez tamtejsze elity polityczne i społeczeństwo. Będzie to służyło odbudowie nadszarpniętego ostatnimi laty zaufania, a docelowo może ułatwić rozwiązanie narosłych problemów. Pozostaje jedynie mieć nadzieję, że nie będziemy potrzebowali kolejnych 20 lat, żeby zrealizować te postulaty.

\section{Bibliografia}

Bukowiecka H., Polityka Polski wobec Litwy, ,,Rocznik Polskiej Polityki Zagranicznej 2008”. Cieplak P., Stosunki polsko-litewskie, „Rocznik Polskiej Polityki Zagranicznej 1992”. 
Dębski S., Rozważania o stosunkach polsko-litewskich na tle porównawczym, „Polski Przegląd Dyplomatyczny" 2001, t. 1, nr 2.

Firewicz A., Litwa po raz drugi, Toruń 2001.

Górka-Winter B., Polsko-litewska współpraca $w$ dziedzinie bezpieczeństwa, „Polski Przegląd Dyplomatyczny" 2001, t. 1, nr 2.

Hyndle J., Kutysz M., Stosunki Polski z Litwa w latach 2004-2006, „Rocznik Polskiej Polityki Zagranicznej 2007'.

Kosman M., Pod ciśnieniem tradycji. Uwagi o współczesnych stosunkach polsko-litewskich, w: Polska polityka zagraniczna w procesie przemian po 1989 roku, red. A. Żukowski, Olsztyn 1999.

Modzelewski W. T., Współczesne polsko-litewskie stosunki polityczne. Zarys problematyki, „Sprawy Wschodnie” 2005, nr 2-3.

Modzelewski W. T., Europejskie bezpieczeństwo energetyczne we współczesnych stosunkach polsko-litewskich, w: Unia Europejska na poczqtku XXI wieku, red. W. Tomaszewski, M. Chełminiak, Olsztyn 2009.

Modzelewski W. T., Stosunki polsko-litewskie, w: Polska wobec sqsiadów. Współczesne stosunki polityczne, red. W. T. Modzelewski, Olsztyn 2009.

Posel-Częścik E., Miejsce Litwy i Polski w przestrzeni transatlantyckiej, „Polski Przegląd Dyplomatyczny" 2001, t. 1, nr 2.

Przybyła S., Podejście Litwy do bezpieczeństwa w regionie, Warszawa 1997.

Stachura J., Stosunki dwustronne Polski: Litwa, Łotwa, Estonia, „Rocznik Polskiej Polityki Zagranicznej 2003”.

Stemplowski R., Następny krok w strategicznym partnerstwie litewsko-polskim?, „Polski Przegląd Dyplomatyczny” 2001, t. 1, nr 2.

Szura-Olesińska O., Stosunki polsko-litewskie, w: Stosunki Polski z sqsiadami w pierwszej dekadzie XXI wieku, red. M. Stolarczyk, Katowice 2011.

Widacki J., Stosunki z Litwa, „Rocznik Polskiej Polityki Zagranicznej 1997”.

Wizimirska B., Stosunki z Litwa, „Rocznik Polskiej Polityki Zagranicznej 1998”.

\section{Two decades of Polish-Lithuanian relations - a political dimension}

\section{Summary}

Lithuania was among the first republics of the disintegrating Soviet Union to announce its declaration of independence, and in September 1991 established diplomatic relations with Poland. In January 1992, both countries signed a joint declaration, and in April 1994 they signed the Treaty on friendly relations and good neighborly cooperation. Over the next 10 years, ways of achieving foreign policy objectives shared by both countries were sought and eventually worked out. Mutual support in pursuit of becoming a member of NATO and of the European Union was 
visible, which eventually turned into profound relations that were referred to as a strategic partnership. A network of cooperation was formed. It included deep political contacts at all levels and the paying of first foreign visits after being sworn in, which on the Polish side was initiated in 1996 by President A. Kwaśniewski, has become a symbol. Both countries have undertaken joint initiatives to improve energy security and military cooperation, and conduct cross-border and interregional cooperation. The end of the second decade of the two countries' relations showed, however, that unresolved problems, mainly related to the status of the Polish minority in Lithuania, have been increasingly influencing the policy of steadily building good neighborly relations between Warsaw and Vilnius. 